\title{
Human telomerase disease mutants and its relation with hepatocarcinoma
}

\author{
Yin-Nan Chen ${ }^{2}$, Yan-Min Zhang ${ }^{1}$ \\ ${ }^{1}$ School of Pharmacy, Health Science Center, Xi'an Jiaotong University, Xi'an 710061, Shaanxi, China. \\ ${ }^{2}$ School of Molecular Sciences, Arizona State University, Tempe, AZ 85287, USA.
}

\begin{abstract}
Telomerase is a special reverse transcriptase, which adds telomeric DNA repeats to the ends of chromosome to offset loss. A vast majority of cancer cells have been shown that their telomerase was up-regulated and sustain proliferation and growth. Hepatocellular carcinoma ( $\mathrm{HCC}$ ) is one of the most commonly occurring cancers worldwide. It is also one of the leading causes of cancer death, and is connected with abnormal telomerase function. However, reports about the telomerase mutations and $\mathrm{HCC}$ are still insufficient. In this review, the structure and mechanism of action of telomerase, inherited disorders caused by its mutations, hepatocarcinoma, and drug development targeting telomerase are reviewed. However, further investigations are needed to elucidate human telomerase RNA gene regulation for initiation and progression of the liver cancer.
\end{abstract}

Key words: Telomerase; mutants; hepatocarcinoma; target

Address for correspondence:

Prof. Yan-Min Zhang, School of Pharmacy, Health Science Center, Xi'an Jiaotong University, Xi'an 710061, Shaanxi, China.

E-mail: zhang2008@mail.xjtu.edu.cn

Received: 06-10-2015, Accepted: 28-01-2016

\section{INTRODUCTION}

Following genome duplication, eukaryotic chromosomes shrink due to the incomplete replication. ${ }^{[1]}$ The end of the chromosomes is capped by DNA-protein complex known as telomere. The progressive loss of telomeric DNA threatens genome stability and limits cell division. ${ }^{[2]}$ Telomerase is a special reverse transcriptase which adds telomeric DNA repeats to the chromosome ends to offset loss. ${ }^{[3]}$ In human, telomerase is inactive in most of the somatic cells but not stem cells and germlines. So far it has been found that a vast majority of cancer cells, their telomerase is up-regulated in order to sustain proliferation and growth. ${ }^{[4]}$ Additionally, telomere mediated disorders such as dyskeratosis congenital, aplastic anemia and idiopathic pulmonary fibrosis have been demonstrated to have telomerase mutations. ${ }^{[5-7]}$

Cancer is one of the world's greatest disease burdens and hepatocellular carcinoma (HCC) is one of the leading

\begin{tabular}{|l|c|}
\hline \multicolumn{2}{|c|}{ Access this article online } \\
\hline \multirow{2}{*}{ Website: } & Quick Response Code \\
http://hrjournal.net/ & \\
\hline & \\
DOI: & \\
10.20517/2394-5079.2015.56 &
\end{tabular}

causes of cancer death especially in Asia and Africa. ${ }^{[8]}$ HCC is induced by the well known risk factors such as hepatitis $\mathrm{B}$, hepatitis $\mathrm{C}$ virus infection as well as cirrhosis. ${ }^{[8,9]}$ In general, it is widely accepted that telomeric shortening is responsible for limiting the life of human somatic cells and the expression of telomerase in the cells is sufficient to overcome both replication as well as senescence. ${ }^{[10]}$ Although the mechanism involved in telomerase regulation has not been completely understood, most types of cancer cells reveal a telomere length maintenance, which is responsible for their immortality. ${ }^{[1,12]}$ Intact telomere signaling has been demonstrated to be essential in the development of HCC. Similar to other types of cancers, it has been shown that around $85 \%$ of human HCC specimens exhibit reactivation of telomerase activity. ${ }^{[13]}$ Transcriptional regulation of the hTERT gene with frequent somatic mutations has been described in several tumor cells including HCC. ${ }^{[14,15]}$ Additionally, weak activation of telomerase has been reported during chronic viral hepatitis or cirrhosis, which could be potential factors

This is an open access article distributed under the terms of the Creative Commons Attribution-NonCommercial-ShareAlike 3.0 License, which allows others to remix, tweak, and build upon the work non-commercially, as long as the author is credited and the new creations are licensed under the identical terms.

For reprints contact: service@oaepublish.com

How to cite this article: Chen YN, Zhang YM. Human telomerase disease mutants and its relation with hepatocarcinoma. Hepatoma Res 2016;2:109-13. 
for development of HCC. ${ }^{[16]}$ Thus, telomerase has been recognized as a relevant factor in distinguishing cancer from normal cells and is a very promising target for anticancer therapy. ${ }^{[17]}$

\section{STRUCTURE AND WORKING MECHANISM OF TELOMERASE}

Telomerase is a unique reverse transcriptase, the core of which is composed of the telomerase reverse transcriptase (TERT) protein and integral telomerase RNA (TR). ${ }^{[18,19]}$ As a ribonucleoprotein, the TR of telomerase provides the template which specifies the telomere repeat sequence and motifs necessary for the activity; the protein is the catalytic component of the enzyme which comprises four conserved structural domains. ${ }^{|20|}$ Unlike TRs which varies in length and secondary structure among different species, TERT proteins are conserved and comprise four structural domains: the telomerase essential $\mathrm{N}$-terminal domain (TEN), the TR binding domain (TRBD), the reverse transcriptase domain (RT) and the C-terminal extension domain (CTE). ${ }^{[20,21]}$

To date, the only complete crystal structure of the TERT protein is from a flour beetle Tribolium castaneum, and subsequent biochemical work showed a DNA/RNA duplex bound to T. castaneum. Interestingly, the TERT as a model of TR bound to substrate DNA resemble those observed in human immunodeficiency virus RT. ${ }^{[2]}$ The recently reported crystal structure of TRBD of TERT and conserved region 4 and 5 of TR from teleost fish Oryzias latipes provides useful information for further investigation into the structure and function of telomease ribonucleoproteins complex. ${ }^{[23]}$ Unfortunately, the whole structure of the human telomerase remains unsolved mainly because of the requirement for highly purified concentrated protein.

Compared with traditional RT, telomerase extend DNA substrate by using its own short RNA as a template. Therefore besides nucleotide addition, telomerase requires a process called template translocation to recycle its template. Furthermore, there are several working models of human telomerase that have been proposed in last few years by biochemical functional assay or single molecular FRET. ${ }^{[24,25]}$ However the detail of this process remains unknown.

\section{MUTANTS AFFECT ENZYME FUNCTION}

Numerous unique mutations within the hTR gene have been found to reduce the levels of active telomerase. Changes in the primary sequence can disrupt RNA base-pairing and local structure, which will affect telomerase function by: (1) reducing the assembly of hTERT and hTR; (2) mis-positioning of the template region; and (3) dissociation of hTR with accessory proteins..$^{[26-28]}$ The reduction in telomerase activity or RNA accumulation is experimentally confirmed and is associated with diseases. Similar to hTR mutations, various unique mutations have been identified within the TERT gene, which are linked to human telomere mediated disorders

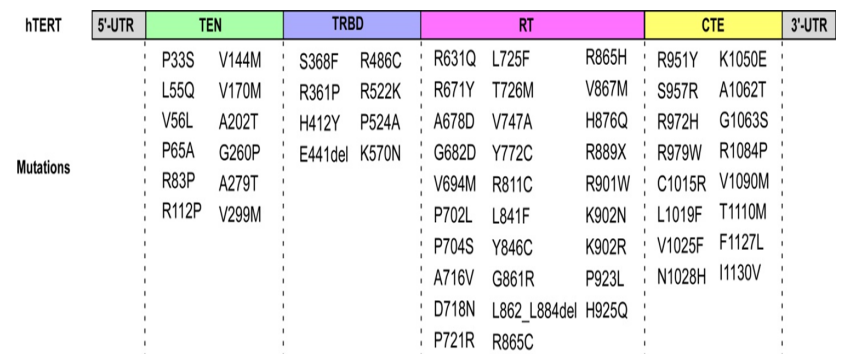

Figure 1. The structural scheme for the four domains of the telomerase reverse transcriptase (TERT) protein with mutations. TERT is composed of four structural domains: telomerase essential $\mathrm{N}$-terminal (TEN), telomerase RNA binding domain (TRBD), reverse transcriptase (RT), and C-terminal extension (CTE). The above structure has indicated the locations of mutations known to cause human diseases.

[Figure 1]. When mapped onto the amino acid sequence, the hTERT mutations are located almost exclusively in the conserved functional domains, especially concentrated within the RT motifs. ${ }^{[29,30]}$ While mutations that disrupt nucleotide addition are well characterized, only those with reduced repeat addition processivity have been discovered recently. ${ }^{[30]}$

Table 1: Human telomerase related disease mutants

\begin{tabular}{|c|c|c|c|}
\hline \multirow[t]{2}{*}{ Diseases } & \multicolumn{3}{|c|}{ Mutations } \\
\hline & TERT & TR & $\begin{array}{c}\text { Accessary } \\
\text { proteins }\end{array}$ \\
\hline Aplastic anemia & $\mathrm{V}$ & $\mathrm{V}$ & $\mathrm{V}$ \\
\hline Acute myeloid leukemia & 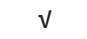 & & \\
\hline Dyskeratosis congenita & 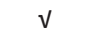 & V & $\sqrt{ }$ \\
\hline Pulmonary fibrosis & V & V & $\mathrm{V}$ \\
\hline Pancytopenia & 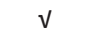 & & \\
\hline Hoyeraal Hreidarsson syndrome & & $\checkmark$ & $\sqrt{ }$ \\
\hline Thrombocytopenia & & V & \\
\hline Paroxysmal nocturnal hemoglobinuria & & V & \\
\hline Bone marrow failure & & & V \\
\hline Myelodysplastic syndrome & $\sqrt{ }$ & & $v$ \\
\hline Nail distrophy & & & $v$ \\
\hline Polymorphism & $\sqrt{ }$ & V & v \\
\hline Hypoplastic myelodysplastic syndrome & & V & \\
\hline Revesz syndrome & & & v \\
\hline Mucocutaneous features & & & $\sqrt{ }$ \\
\hline Intrauterine frowth retardation & & & $\sqrt{ }$ \\
\hline Menorrhagia & & $\sqrt{ }$ & \\
\hline
\end{tabular}

TERT: telomerase reverse transcriptase; TR: telomerase RNA

\section{THE INHERITED DISORDERS CAUSED BY THE TELOMERASE MUTATIONS}

The hTERT and hTR genes are considered the common cause of inherited human telomerase mediated disease. Numerous mutations within hTERT and hTR including substitution, additions and deletions have been shown connected to inherited disorders that lead to diseases. Congenital dyskeratosis, aplastic anemia and idiopathic pulmonary fibrosis have been demonstrated linking to mutations within the genes that encode for two telomerase core components hTERT and hTR as well as telomerase associated proteins [Table 1]. ${ }^{[31-33]}$ The maintenance of telomere length in highly 
prolific cells, stem cells and germline, is crucial for the preservation of high populations and human health. ${ }^{[34}$ Generally, point mutations that lead to single substitution of amino acid are more likely tolerated than frame shift and splicing junction mutations, limiting but not abolishing the enzyme activity. The toleration of reduction and loss of telomerase function decreases with several subsequent generations. The telomeres of the parental generation erode when passed to the offspring with shorter telomeres. The increase in severity of symptoms is linked with the progressive decrease to telomere length. ${ }^{[35]}$

\section{HEPATOCARCINOMA WITH EXPRESSION OF ACTIVE TELOMERASE}

The relationship between telomerase mutation and development of hepatocellular carcinoma is controversial and inconclusive so far. ${ }^{[13]}$ Telomeres within HCC were shorter compared to normal liver cells suggesting that it could escape the DNA damage response and subsequent cell cycle arrest signal generated from short telomeres. It has been suggested that telomere shortening may represent a genetic risk factor for the development of cirrhosis. ${ }^{[3]}$ The beneficial effects of the telomere and telomerase system plays a role for suppression of the development of liver cirrhosis and HCC in gene knock out mouse model which was performed by Wiemann et al. ${ }^{[37]}$ and Kitada et al..$^{[38]}$

However, some studies of HBV-associated HCC have demonstrated that longer telomeres and higher telomerase activity correlates with a worse prognosis. The expression of dyskerin, the accessory component of telomerase complex, showed a correlation with tumorigenic process, which might be a prognostic factor in patients with HCC. ${ }^{[39]}$ A nuclear ribonucleoprotein A2/B1, an hTERT-associated protein was proposed as a marker and prognosis factor of HCC. ${ }^{[40]}$ The study by Lechel et al. ${ }^{[41]}$ provides direct evidence that telomerase is a critical component for in vivo progression HCC with short telomeres in the chronically damaged liver and telomerase limits the accumulation of telomere dysfunction thus suppressing hepatocarcinogenesis. Taken together, short telomeres or telomere dysfunction appears permissive for the development of early stage neoplasia, but inhibitory to later stage and more anaplastic lesions. ${ }^{[42]}$

Transcriptional regulation of the TERT gene is a cause of cancer specific increase in telomerase activity. ${ }^{[43]}$ Quaas et al. ${ }^{[44]}$ and other researchers have shown the mutations on promoter region of hTERT in hepatocellular carcinoma. Meanwhile, several reports have shown that increase in telomerase activity was detected in nearly $90 \%$ of HCC as compared to only $21 \%$ of non-tumor tissue which resulted in increased levels of TERT mRNA implying that TERT mRNA expression could predict or be a marker of HCC..$^{[45,46]}$ Recent study from Cevik et al..$^{[47]}$ hTERT promoter is one of most frequent mutational targets in liver cancer regardless of the geographical location and two site mutation (C228T AND
C250T) showed very high frequency in HCC. Furthermore, large scale studies by Huang et al. ${ }^{[43]}$ identified TERT promoter mutations to be $31.4 \%$ in HCC which shows high frequency similar like other primary cancers.

Cirrhosis is a disease in which liver cells become damaged and is replaced by scar tissues. People with cirrhosis have an increased risk of liver cancer. Most people who develop liver cancer already have some evidence of cirrhosis. Evidence supporting the role of genetic risk factors has been accumulating during the past years and recently it has been also suggested that telomere shortening may represent a genetic risk factor. ${ }^{[12]}$ Valenti et al..$^{[4]}$ found that HCC arising from cirrhosis contained a TERT mutation in the neoplastic tissue. Furthermore, studies from Hartmann et al. ${ }^{[16]}$ provides experimental evidence that telomerase gene mutations are present in patients who develop cirrhosis as a consequence of chronic liver disease.

\section{DRUG RESEARCH AND DEVELOPMENT FOR CANCER WITH TELOMERASE AS TARGET}

A fundamental property of the cancer cells is to replicate without limitation, which is achieved by telomerase-regulated telomere maintenance in most types of cancer cells. Since somatic cells do not utilize activated telomerase to keep the integrity of the telomere length, the telomerase inhibitors have the potential to be a selective anti-cancer agents to disrupt the proliferation of the telomerase-positive cancer cells. ${ }^{[1]}$ Oligonucleotide can interact with both telomerase RNA and mRNA of telomerase proteins, therefore native or modified oligonucleotides are considered to be potential telomerase inhibitors that can influence the biogenesis of telomerase core components. A promising oligonucleotide, GRN163L, has been developed as telomerase inhibitor, which acts as competitive inhibitor for the template region of the hTR. ${ }^{[49,50]}$ The compound has already completed phase I trials in patients and now being conducted for phase II trials. ${ }^{[51]}$ To trigger cancer cells death, it requires a period of treatment of telomerase inhibitor to produce enough short telomeres. However, the therapy may be more effective when combined with conventional chemotherapies.

Some of the telomerase inhibitors have been found in microbes, which target either telomerase holoenzyme activity or regulatory pathways of telomerase expression. Among anticancer compounds, the inhibitors are promising for the chemotherapy by virtue of differential expression of telomerase in cancer cells. Synthetic preparation or modification of already screened natural telomerase inhibitor will become useful weapons in the war against cancer e.g. BIBR 1532. ${ }^{[52]}$ Most recently the co-crystal structure of telomerase inhibitor BIBR 1532 with Tribolium castaneum telomerase catalytic subunit showed a novel motif on the thumb domain could be a target for inhibiting telomerase function. ${ }^{[53]}$ Kellermann et al. ${ }^{[54]}$ identified a compound that prevent the assembling of the core enzyme and revealed a 
target for screening small molecules capable to interfere with telomerase assembly. Indeed, for macromolecular complex, the interfacial drugs have a remarkable potential application.

G-quadruplex stabilizers are potent ligands that indirectly target telomerase resulting in inhibition of its activity. BRACO-19, RHPS4 and Telomestatin are commonly studied G-quadruplex binding ligands. Recently there are several studies showed anticancer drug candidates with G-guadruplex as targets. ${ }^{[55,56]}$

Immunotherapy approach which induces $\mathrm{T}$ lymphocytes to respond to hTERT antigens in malignant tumor has shown good inhibitory effect. Preclinical studies with hTERT peptides have led to successful progress in the telomerasetargeting immunotherapies. Some telomerase vaccination such as Vx-001, GV1001 showed promising clinical outcome for different types of tumor. ${ }^{[57,58]}$ Recently an hTERT-derived peptide [hTERT(461)] have shown clinical benefits in HCC patients. ${ }^{[59]}$

\section{CONCLUSION AND PERSPECTIVE}

Telomere shortening plays an important role in cell senescence. Telomerase which maintains the length of telomere connects with aging, chronic diseases as well as cancer promotion and progression. ${ }^{[17,34]}$ By looking into the telomerase gene mutations, the relation between the mutants and liver disease including HCC probably is due to the reduced activity. Meanwhile, the mutations at noncoding sequence of the telomerase also involved in the development of the HCC by regulating the expression level of active enzyme. It is commonly believed that the expression of hTERT may be a definitive factor in the activation of telomerase in hepatocarcinogenesis, ${ }^{[46]}$ however according to the recent paper from Xi et al. ${ }^{[60]}$ overexpression of either hTR or hTERT could increase telomerase activity which indicates that the two core components assemble into active telomerase is an equilibrium process. Further investigation is required to elucidate the regulation of hTR gene with initiation and progression of the liver cancer.

\section{Financial support and sponsorship}

This work was supported by the National Natural Science Foundation of China (Grant no. 81370088) and the Supporting Plan of Education Ministry's New Century Excellent Talents (Grant no. NCET-13-0467).

\section{Conflicts of interest}

There are no conflicts of interest.

\section{REFERENCES}

1. $\quad$ de Lange T. Protection of mammalian telomeres. Oncogene 2002;21:53240 .

2. de Lange T. How telomeres solve the end-protection problem. Science 2009;326:948-52.

3. Lingner J, Cooper JP, Cech TR. Telomerase and DNA end replication - no longer a lagging-strand problem? Science 1995;269:1533-4.
4. Kim NW, Piatyszek MA, Prowse KR, Harley CB, West MD, Ho PL, Coviello GM, Wright WE, Weinrich SL, Shay JW. Specific association of human telomerase activity with immortal cells and cancer. Science 1994;266:2011-5.

5. Fogarty PF, Yamaguchi H, Wiestner A, Baerlocher GM, Sloand E, Zeng WS, Read EJ, Lansdorp PM, Young NS. Late presentation of dyskeratosis congenita as apparently acquired aplastic anaemia due to mutations in telomerase RNA. Lancet 2003;362:1628-30.

6. Armanios MY, Chen JJ, Cogan JD, Alder JK, Ingersoll RG, Markin C, Lawson WE, Xie MY, Vulto I, Phillips JA 3rd, Lansdorp PM, Greider CW, Loyd JE. Telomerase mutations in families with idiopathic pulmonary fibrosis. N Engl J Med 2007;356:1317-26.

7. Vulliamy TJ, Marrone A, Knight SW, Walne A, Mason PJ, Dokal I. Mutations in dyskeratosis congenita: their impact on telomere length and the diversity of clinical presentation. Blood 2006;107:2680-5.

8. Tsukuma H, Tanaka H, Ajiki W, Oshima A. Liver cancer and its prevention. Asian Pac J Cancer Prev 2005;6:244-50.

9. Ding D, Lou X, Hua D, Yu W, Li L, Wang J, Gao F, Zhao N, Ren G, Li $\mathrm{L}$, Lin B. Recurrent targeted genes of hepatitis B virus in the liver cancer genomes identified by a next-generation sequencing-based approach. PLoS Genet 2012;8:e1003065.

10. Collins K, Mitchell JR. Telomerase in the human organism. Oncogene 2002;21:564-79.

11. Hanahan D, Weinberg RA. The hallmarks of cancer. Cell 2000;100:57-70.

12. Carulli L, Anzivino C. Telomere and telomerase in chronic liver disease and hepatocarcinoma. World J Gastroenterol 2014;20:6287-92.

13. Satyanarayana A, Manns MP, Rudolph KL. Telomeres and telomerase: a dual role in hepatocarcinogenesis. Hepatology 2004;40:276-83.

14. Quaas A, Oldopp T, Tharun L, Klingenfeld C, Krech T, Sauter G, Grob TJ. Frequency of TERT promoter mutations in primary tumors of the liver. Virchows Arch 2014;465:673-7.

15. Fujimoto A, Totoki Y, Abe T, Boroevich KA, Hosoda F, Nguyen HH, Aoki M, Hosono N, Kubo M, Miya F, Arai Y, Takahashi H, Shirakihara T, Nagasaki M, Shibuya T, Nakano K, Watanabe-Makino K, Tanaka H, Nakamura H, Kusuda J, Ojima H, Shimada K, Okusaka T, Ueno M, Shigekawa Y, Kawakami Y, Arihiro K, Ohdan H, Gotoh K, Ishikawa O, Ariizumi S, Yamamoto M, Yamada T, Chayama K, Kosuge T, Yamaue H, Kamatani N, Miyano S, Nakagama H, Nakamura Y, Tsunoda T, Shibata T, Nakagawa $H$. Whole-genome sequencing of liver cancers identifies etiological influences on mutation patterns and recurrent mutations in chromatin regulators. Nat Genet 2012;44:760-4.

16. Hartmann D, Srivastava U, Thaler M, Kleinhans KN, N'kontchou G, Scheffold A, Bauer K, Kratzer RF, Kloos N, Katz SF, Song Z, BegusNahrmann Y, Kleger A, von Figura G, Strnad P, Lechel A, Günes C, Potthoff A, Deterding K, Wedemeyer H, Ju Z, Song G, Xiao F, Gillen S, Schrezenmeier H, Mertens T, Ziol M, Friess H, Jarek M, Manns MP, Beaugrand M, Rudolph KL. Telomerase gene mutations are associated with cirrhosis formation. Hepatology 2011;53:1608-17.

17. Buseman CM., Wright WE, Shay JW. Is telomerase a viable target in cancer? Mutat Res 2012;730:90-7.

18. Shippenlentz D, Blackburn EH. Functional evidence for an rna template in telomerase. Science 1990;247:546-52

19. Weinrich SL, Pruzan R, Ma L, Ouellette M, Tesmer VM, Holt SE, Bodnar AG, Lichtsteiner S, Kim NW, Trager JB, Taylor RD, Carlos R, Andrews WH, Wright WE, Shay JW, Harley CB, Morin GB. Reconstitution of human telomerase with the template RNA component hTR and the catalytic protein subunit hTRT. Nat Genet 1997;17:498-502.

20. Nakamura TM, Morin GB, Chapman KB, Weinrich SL, Andrews WH, Lingner J, Harley CB, Cech TR. Telomerase catalytic subunit homologs from fission yeast and human. Science 1997;277:955-9.

21. Yu RM, Chen EX, Kong RY, Ng PK, Mok HO, Au DW. Hypoxia induces telomerase reverse transcriptase (TERT) gene expression in non-tumor fish tissues in vivo: the marine medaka (Oryzias melastigma) model. BMC Mol Biol 2006; 7:27.

22. Gillis AJ, Schuller AP, Skordalakes E. Structure of the tribolium castaneum telomerase catalytic subunit TERT. Nature 2008;455:633-47.

23. Huang J, Brown AF, Wu J, Xue J, Bley CJ, Rand DP, Wu LJ, Zhang RG, Chen JJ, Lei M. Structural basis for protein-RNA recognition in telomerase. Nat Struct Mol Biol 2014;21:507-12. 
24. Qi X, Xie M, Brown AF, Bley CJ, Podlevsky JD, Chen JJ. RNA/DNA hybrid binding affinity determines telomerase template-translocation efficiency. EMBO J 2012;31:150-61.

25. Parks JW, Stone MD. Coordinated DNA dynamics during the human telomerase catalytic cycle. Nat Commun 2014;5:4146.

26. Theimer CA, Jády BE, Chim N, Richard P, Breece KE, Kiss T, Feigon J. Structural and functional characterization of human telomerase RNA processing and cajal body localization signals. Mol Cell 2007;27:869-81.

27. Cristofari G, Adolf E, Reichenbach P, Sikora K, Terns RM, Terns MP, Lingner J. Human telomerase RNA accumulation in Cajal bodies facilitates telomerase recruitment to telomeres and telomere elongation Mol Cell 2007;27:882-9.

28. Robart AR, Collins K. Investigation of human telomerase holoenzyme assembly, activity, and processivity using disease-linked subunit variants. J Biol Chem 2010;285:4375-86

29. Podlevsky JD, Bley CJ, Omana RV, Qi X, Chen JJ. The telomerase database. Nucleic Acids Res 2008;36:D339-43.

30. Alder JK, Cogan JD, Brown AF, Anderson CJ, Lawson WE, Lansdorp PM, Phillips JA 3rd, Loyd JE, Chen JJ, Armanios M. Ancestral mutation in telomerase causes defects in repeat addition processivity and manifests as familial pulmonary fibrosis. PLoS Genet 2011;7:e1001352.

31. Armanios M. Telomerase and idiopathic pulmonary fibrosis. Mutat Res 2012;730:52-8.

32. Nishio N, Kojima S. Recent progress in dyskeratosis congenita. Int $J$ Hematol 2010;92:419-24.

33. Vulliamy T, Marrone A, Dokal I, Mason PJ. Association between aplastic anaemia and mutations in telomerase RNA. Lancet 2002;359:2168-70.

34. Hoare M, Das T, Alexander G. Ageing, telomeres, senescence, and liver injury. J Hepatol 2010;53:950-61.

35. Podlevsky JD, Chen JJ. It all comes together at the ends: telomerase structure, function, and biogenesis. Mutat Res 2012;730:3-11.

36. Carulli L. Telomere shortening as genetic risk factor of liver cirrhosis World J Gastroenterol 2015;21:379-83.

37. Wiemann SU, Satyanarayana A, Tsahuridu M, Tillmann HL, Zender L, Klempnauer J, Flemming P, Franco S, Blasco MA, Manns MP, Rudolph KL. Hepatocyte telomere shortening and senescence are general markers of human liver cirrhosis. FASEB J 2002;16:935-42.

38. Kitada T, Seki S, Kawakita N, Kuroki T, Monna T. Telomere shortening in chronic liver-diseases. Biochem Biophys Res Commun 1995;211:33-9.

39. Liu B, Zhang JL, Huang C, Liu H. Dyskerin overexpression in human hepatocellular carcinoma is associated with advanced clinical stage and poor patient prognosis. PLoS One 2012;7:e43147.

40. Mizuno H, Honda M, Shirasaki T, Yamashita T, Yamashita T, Mizukoshi E, Kaneko S. Heterogeneous nuclear ribonucleoprotein A2/B1 in association with hTERT is a potential biomarker for hepatocellular carcinoma. Liver Int 2012;32:1146-55.

41. Lechel A, Holstege H, Begus Y, Schienke A, Kamino K, Lehmann U, Kubicka S, Schirmacher P, Jonkers J, Rudolph KL. Telomerase deletion limits progression of p53-mutant hepatocellular carcinoma with short telomeres in chronic liver disease. Gastroenterology 2007;132:1465-75.

42. Farazi PA, Glickman J, Jiang S, Yu A, Rudolph KL, DePinho RA. Differential impact of telomere dysfunction on initiation and progression of hepatocellular carcinoma. Cancer Res 2003;63:5021-7.

43. Huang DS, Wang Z, He XJ, Diplas BH, Yang R, Killela PJ, Meng Q, Ye ZY, Wang W, Jiang XT, Xu L, He XL, Zhao ZS, Xu WJ, Wang HJ, Ma YY, Xia YJ, Li L, Zhang RX, Jin T, Zhao ZK, Xu J, Yu S, Wu F, Liang J, Wang S, Jiao Y, Yan H, Tao HQ. (2015) Recurrent TERT promoter mutations identified in a large-scale study of multiple tumour types are associated with increased TERT expression and telomerase activation. Eur J Cancer 2015;51:969-76.
44. Quaas A, Oldopp T, Tharun L, Klingenfeld C, Krech T, Sauter G, Grob TJ. Frequency of TERT promoter mutations in primary tumors of the liver. Virchows Arch 2014;465:673-7.

45. Nagao K, Tomimatsu M, Endo H, Hisatomi H, Hikiji K. Telomerase reverse transcriptase mRNA expression and telomerase activity in hepatocellular carcinoma. J Gastroenterol 1999;34:83-7.

46. Shimojima M, Komine F, Hisatomi H, Shimizu T, Moriyama M, Arakawa Y. (2004) Detection of telomerase activity, telomerase RNA component, and telomerase reverse transcriptase in human hepatocellular carcinoma. Hepatol Res 2004;29:31-8.

47. Cevik D, Yildiz G, Ozturk M. Common telomerase reverse transcriptase promoter mutations in hepatocellular carcinomas from different geographical locations. World J Gastroenterol 2015;21:311-7.

48. Valenti L, Dongiovanni P, Maggioni M, Motta BM, Rametta R, Milano M, Fargion S, Reggiani P, Fracanzani AL. Liver transplantation for hepatocellular carcinoma in a patient with a novel telomerase mutation and steatosis. J Hepatol 2013;58:399-401.

49. Dikmen ZG, Gellert GC, Jackson S, Gryaznov S, Tressler R, Dogan P, Wright WE, Shay JW. In vivo inhibition of lung cancer by GRN163L: a novel human telomerase inhibitor. Cancer Res 2005;65:7866-73.

50. Burchett KM, Yan Y, Ouellette MM. Telomerase inhibitor Imetelstat (GRN163L) limits the lifespan of human pancreatic cancer cells. PloS One 2014;9:e85155.

51. Molckovsky A, Siu LL. First-in-class, first-in-human phase I results of targeted agents: highlights of the 2008 American society of clinical oncology meeting. J Hematol Oncol 2008;1:20.

52. Parsch D, Brassat U, Brümmendorf TH, Fellenberg J. Consequences of telomerase inhibition by BIBR 1532 on proliferation and chemosensitivity of chondrosarcoma cell lines. Cancer Invest 2008;26:590-6.

53. Bryan C, Rice C, Hoffman H, Harkisheimer M, Sweeney M, Skordalakes E. Structural basis of telomerase inhibition by the highly specific BIBR1532. Structure 2015;23:1934-42.

54. Kellermann G, Kaiser M, Dingli F, Lahuna O, Naud-Martin D, MahuteauBetzer F, Loew D, Ségal-Bendirdjian E, Teulade-Fichou MP, Bombard S. Identification of human telomerase assembly inhibitors enabled by a novel method to produce hTERT. Nucleic Acids Res 2015;43:e99.

55. Chen ZF, Qin QP, Qin JL, Zhou J, Li YL, Li N, Liu YC, Liang H. Watersoluble ruthenium(II) complexes with chiral 4-(2,3-dihydroxypropyl)formamide oxoaporphine (FOA): in vitro and in vivo anticancer activity by stabilization of G-quadruplex DNA, inhibition of telomerase activity, and induction of tumor cell apoptosis. J Med Chem 2015;58:4771-89.

56. Wei C, Ren L, Gao N. Interactions of terpyridines and their Pt(II) complexes with G-quadruplex DNAs and telomerase inhibition. Int $J$ Biol Macromol 2013;57:1-8.

57. Staff C, Mozaffari F, Frodin JE, Mellstedt H, Liljefors M. Telomerase (GV1001) vaccination together with gemcitabine in advanced pancreatic cancer patients. Int J Oncol 2014;45:1293-303.

58. Kotsakis A, Papadimitraki E, Vetsika EK, Aggouraki D, Dermitzaki EK, Hatzidaki D, Kentepozidis N, Mavroudis D, Georgoulias V. A phase II trial evaluating the clinical and immunologic response of HLA-A2(+) non-small cell lung cancer patients vaccinated with an hTERT cryptic peptide. Lung Cancer 2014;86:59-66.

59. Mizukoshi E, Nakagawa H, Kitahara M, Yamashita T, Arai K, Sunagozaka H, Fushimi K, Kobayashi E, Kishi H, Muraguchi A, Kaneko $\mathrm{S}$. Immunological features of $\mathrm{T}$ cells induced by human telomerase reverse transcriptase-derived peptides in patients with hepatocellular carcinoma. Cancer Lett 2015;364:98-105.

60. Xi LH, Cech TR. Inventory of telomerase components in human cells reveals multiple subpopulations of hTR and hTERT. Nucleic Acids Res 2014;42:8565-77. 